\title{
Algunas fuentes compositivas de la pintura de costumbres en América Latina
}

\section{Some Compositive Sources of Latin American Custom Scene Paintings}

\author{
Guadalupe Álvarez de Araya Cid \\ Universidad de Chile, Departamento de Teoría de las Artes, \\ Facultad de Artes. Santiago, Chile \\ galvarez@uchile.cl
}

Resumen • El estudio de la índole de las tramas a través de las cuales la escena de costumbres se fue distinguiendo de la escena de género y de la pintura de historia, por una parte, y de su relación más compleja aun con el paisaje, por la otra, debiera participar en la comprensión que tengamos del proceso de inscripción de América Latina en el Rococó y el Neoclasicismo. El presente trabajo considera a las soluciones compositivas como fundamento de los campos semánticos de la pintura y revisa algunas soluciones compositivas que confluyeron en la constitución del género «Escena de costumbres» en América Latina, en el periodo comprendido entre el fin del siglo XVIII y principios del siglo XIX.

Palabras clave: semiosis, composición, escena, costumbres, tipología.

Abstract - The analysis of the processes that distinguished custom scenes from genre scenes and historical painting, on the one hand, and its very complex connections with landscape, on the other, should be part of the understanding we have about the Latin-American inscription process to Rococo and Neoclassicism. The current paper will consider compositive solutions as a foundation of the semantics of Paintings and it will review some of the compositive solutions that took part in the constitution of the "custom scene» genre in Latin America towards the late XVIII-early XIX centuries.

Keywords: semiosis, composition, scene, costumbrista, typology. 


\section{CONSIDERACIONES PREVIAS}

El objeto habitual de los estudios sobre la producción de imágenes en América Latina ha sido el examen de los procesos de construcción identitaria. Más recientemente, el enfoque general de esos análisis orienta las investigaciones hacia el campo de las relaciones de poder, giro que ha dado un nuevo matiz a los temas clásicos de lo americano. De entre ellos, sin duda el más recurrente es el de los enunciados con los cuales se ha representado y auto-representado la raza. Por ello, la pintura de costumbres ha sido considerada particularmente significativa. Una posible vía para el estudio de estas imágenes es el examen de los procesos a través de los cuales se fueron distinguiendo la pintura de historia de la escena de género, la escena de costumbres y del más problemático paisaje. El camino que proponemos aquí supone la asunción de los regímenes compositivos como fundamento de la semiosis visual de las obras. Entendemos por semiosis visual al conjunto de mecanismos y procedimientos a través de los cuales tanto el artista —en la distribución de figuras sobre la superficie pictórica- como el espectador —en el acto interpretativo-, operan sobre la base de un conjunto de convenciones de carácter sintáctico-semántico que administran el espacio y que posibilitan tanto la narración de la historia como la interpretación de las mismas. Este tipo de convenciones contemplan una dimensión jerárquica del espacio, así como una dimensión metafórico-metonímica que posibilita la interpretación de las obras en cuanto discurso. Como es evidente, estamos limitando este concepto de semiosis visual a aquellas obras producidas bajo el imperio de la mimesis y la verosimilitud entre los siglos XV y finales del XIX. Asimismo, estamos restringiendo su uso a la dimensión jerárquico-semántica de los regímenes de administración de la superficie pictórica en relación a los regímenes perspectivos convocados en las obras en cuestión. Habremos de distinguir, además, entre la escena de género, la escena de costumbres y la pintura costumbrista. De la primera diremos que se despliega a través de los siglos XVI al XVIII y que orienta sus fines temáticos hacia la edificación moral, religiosa y espiritual. Destacaremos de la escena de costumbres su función tanto descriptiva como evocativa de mundos lejanos (es decir, como perteneciente al largo eje del exotismo o exotismos). Finalmente, consideraremos a la pintura costumbrista como aquella pintura que se elaboró en el periodo comprendido aproximadamente entre 1840 y 1900, en el marco de los procesos de construcción, consolidación y modernización de las naciones latinoamericanas, en cuyo interior, habrá nuevos matices temáticos y compositivos que destacar. Sin embargo, esta comunicación se detendrá en la primera mitad del siglo XIX latinoamericano.

Tres acuerdos generales debieran asistir este enfoque, los tres referidos al arte europeo, pero con implicancias en el arte latinoamericano del último tercio del siglo XVIII y primer tercio del siglo XIX. Uno, que la escena de costumbres es un fenómeno que si bien se populariza en el marco de las expediciones científicas del fin del siglo XVIII, la misma fue objeto de consumo a través de la estampa y de la imprenta ya en el albor del Barroco y, en este mismo sentido, que la escena de costumbres establecía ya en aquel entonces un vínculo problemático con la crónica de viajes, lo que permitiría suponer no sólo una suerte de campo de sentidos, básico para las imágenes ampliamente aceptado y en circulación, cuyos fundamentos estriban más en las convenciones administrativas de la superficie pictórica que en las implicancias de verosimilitud de la imagen, aunque éste sea un presupuesto indiscutido: se trataría del caso en que las soluciones compositivas constituyen el marco de gusto al mismo tiempo que el campo convencional clasificatorio 
básico para el carácter de las imágenes en cuanto escena de costumbres». Dos, que si bien en el transcurso del Barroco y del Tardobarroco, la escena de costumbres se distancia de la escena de género en sus estrategias compositivas y objetivos cognoscitivos, ellas se encuentran, por así decir, en el marco de la práctica académica del Rococó precisamente porque la escena de costumbres amplía momentáneamente lo que había sido su soporte habitual, el libro, para constituirse en imagen pictórica y motivo decorativo para las artes útiles. Y tres, aunque no menos importante, que la forma más notable de difusión del Neoclasicismo fue precisamente el conjunto de transformaciones que generó en la práctica y en las orientaciones pedagógicas de la Academia en un momento en que está aún en vigencia el Rococó (sobre todo en las artes útiles), y no necesariamente en las transformaciones estilísticas que exhibían los propios objetos de artes visuales.

Estimo que un rastreo sistemático de los regímenes compositivos de la tríada escena de género, escena de costumbres y paisaje será de gran ayuda para la periodización del Tardobarroco, el Rococó, y las introducciones no menos problemáticas del Neoclasicismo y el Romanticismo en una América Latina que experimentará un acelerado proceso de laicización a través de la escena de castas, la escena de costumbres, el retrato y el paisaje. Paisaje, a su vez, que abandona el patronazgo de la Inmaculada del siglo XVII latinoamericano e ingresa en la crónica histórica a finales del mismo siglo. No parece necesario insistir, por ahora, en la superposición de géneros que atravesaron estos periodos en ambos extremos del mundo, ni en la relevancia convencionalmente asignada a la Pintura Costumbrista en el proceso de constitución de identidades nacionales.

En el conjunto de acuerdos que establecimos anteriormente, salta a la vista algo que, si bien está implícito en todas las imágenes y narraciones de que disponemos sobre el periodo que nos ocupa, no lo hacía de la manera tan evidente como lo ha hecho aquí: el libro, cuyos modos corporales de recepción claramente difieren del tipo de contemplación que reclama la pintura en sentido tradicional. En efecto, ello es claramente perceptible en el tipo de imágenes producidas por los artistas viajeros del primer tercio del siglo XIX que no pertenecían a las expediciones científicas: la disposición de la imagen y la posición del horizonte en la superficie pictórica es resuelta, con relativa probabilidad, considerando el hecho de que dichas imágenes habrían de circular principalmente bajo la forma de un cartapacio de viajes (Figuras 1 y 2 ).

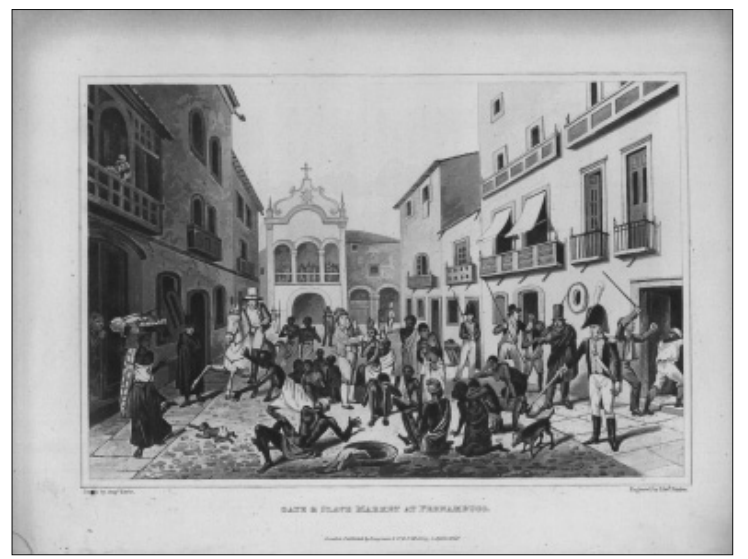

Fig. 1. María Graham: Vía y mercado de esclavos en Pernambuco. Journal of a Voyage to Brazil, 1824. Cortesía de la División de Libros Raros, Biblioteca del Congreso, Washington DC. 


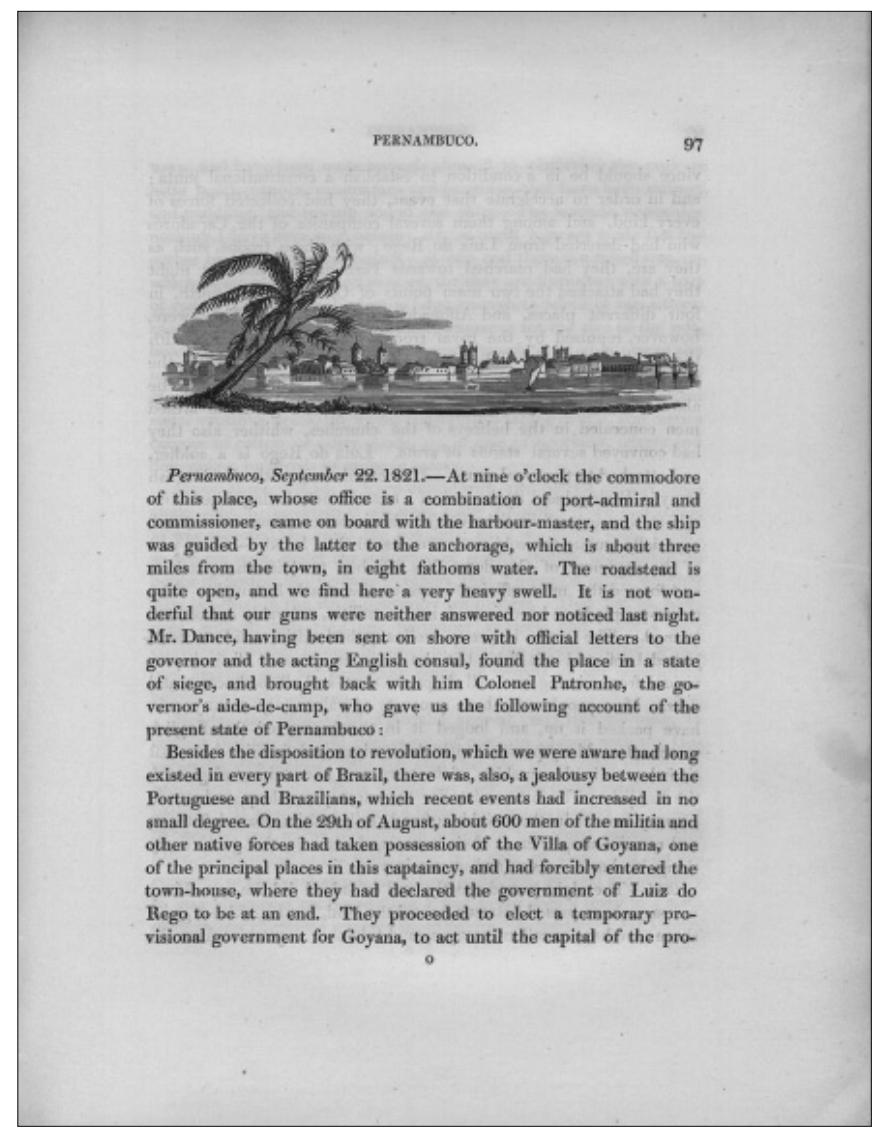

Fig. 2. María Graham: Viñeta ilustrando una vista de Pernambuco. Journal of a Voyage to Brazil, 1824. Cortesía de la División de Libros Raros, Biblioteca del Congreso, Washington DC.

Como sabemos, las Academias de Dibujo y Pintura en Latinoamérica se instalan en el marco de las Reformas de Carlos III y las sugerencias renovadoras de Campomanes. La tesis de Campomanes $(1774,1775)$, recogida por Carlos III, fue la misma tesis que generó la reforma neoclásica de las academias europeas en las que el arte, y sobre todo el dibujo, eran entendidos a la vez como forma de conocimiento y como instrumento útil al desarrollo de la industria. Así mismo, una serie de virtudes morales se le atribuían a la práctica del dibujo que permitían salvar la distancia impuesta por el carácter utilitario que adquirían las artes visuales en el contexto económico-productivo, sobre el imperativo de configuración de un ideal que impulsaba el Neoclasicismo (Pevsner, 1974). Y es bajo el amparo de tales reformas que pretendían impulsar la industria y el comercio, que Carlos III aprobó y financió las expediciones de Mutis y Malaspina. Sin embargo, los artistas del periodo $1780-1840$ no pueden (como no puede hacerlo ningún artista) desprenderse totalmente de los regímenes compositivos que han caracterizado históricamente la producción de imágenes al interior de los marcos -difusos, es cierto- de los géneros pictóricos. En la medida en que entendemos la composición como discurso, de la misma manera como consta en los tratados de los siglos XV, XVI y XVII, y a pesar de 
que su concepto de discurso fuera diferente del contemporáneo, debemos prestar mayor atención a los regímenes compositivos de las imágenes y considerar en su estudio el hecho de que encontraban en el libro su principal y eminente espacio de difusión. Es más, aun cuando podamos conducir nuestros procedimientos metodológicos hacia el análisis de los mecanismos de auto-representación, no podemos olvidar que los campos semánticos de la pintura apuntan en primer lugar a un universo muchísimo más amplio que el del auto-discurso de la pintura.

\section{PINTURA DE HISTORIA, ESCENA DE GÉNERO, PINTURA DE CASTAS}

Examinemos brevemente el caso de la pintura de castas desde la perspectiva de los regímenes compositivos de las series de vidas de santos. Como se sabe, las series de vidas de santos aparecen en el contexto del crecimiento de las devociones particulares en el que transita, entre los siglos IX y XII. Su punto de partida visual radica en las tablas de altar, mismas que aparecen a fines del siglo IX. En ellas, la vida del santo es tratada en una retícula organizada en torno de una imagen central (la imagen del santo) o «imago». En cierta medida, la «imago» posibilitaba la coexistencia de las diversas escenas puesto que todas ellas son parte «sustantiva» de la vida del santo y fungía de centro en el cual gravitaban las diversas escenas. El Renacimiento concibió la pintura de historia ante todo como aquella que narra «una acción» y sustituyó la superposición narrativa por la escena única, dominada por el imperativo de la unidad aristotélica: unidad de acción, tiempo y lugar. Si bien el Renacimiento no abundó en series de vidas de santos, práctica que era más bien medieval, los alardes manieristas en el manejo del espacio y del encuadre, explotaron lo que en el barroco católico será norma: la violación de la unidad espaciotemporal de la escena renacentista y su sustitución por la multiplicidad espacio-temporal de la narración característica de las series de vidas de santos. Para verificar tal ampliación narrativa, las series de vidas de santos aprovecharon una serie de convenciones arcaicas, especialmente las que instituían el uso de elementos arquitectónicos (muros, ventanas, puertas, edificios) que posibilitaban el tránsito de una escena a la que sigue. A su vez, la retórica interior-exterior y su conveniente organización en plano de cielo y plano de tierra, consumaron el tránsito narrativo desde lo que aconteció antes (en un lugar), hacia lo que aconteció después (en otro lugar) en la vida del santo. En efecto, el concepto de escena renacentista suponía la selección de una única escena, lo suficientemente poderosa como para evocar en la mente del espectador, lo que aconteció antes y después de la escena seleccionada. Algo así como la "punta del iceberg», que oculta el grueso del fluir narrativo bajo el océano del saber compartido. La pintura de series de vidas de santos, en cambio, reúne en un ciclo regido por la unidad de la finalidad de la acción, una serie de pequeños episodios de la vida del santo, reduciendo al máximo el silencio narrativo. ${ }^{1}$ Resulta evidente, entonces, que la intención de la Contrarreforma era la de minimizar la ambigüedad interpretativa que imponía el criterio de la escena única, mediante la introducción de secuencias narrativas específicas que «materializaran» la narración, de acuerdo a los principios de paralelismo y homogeneidad.

Algunas de estas soluciones compositivas han sido descritas por Stoichita (1995). 
Por otra parte, la pintura de castas, de amplia producción y consumo en el siglo XVIII, presenta un cuádruple marco tributario (los modelos compositivos del retrato en cuerpo entero y medio, la simultaneidad narrativa de las series de vidas de santos, los modelos compositivos de la escena de género y de la escena de batalla dieciochesca y, por último, los modelos compositivos de las ilustraciones tipológicas tomadas del libro y que comentaremos más adelante). En efecto, la pintura de castas aprovechó las convenciones narrativas de las series de vidas de santos para dotarla tanto de funciones moralizantes como descriptivas de las mezclas raciales, desde una perspectiva tipológica social (tipos productivos) y caracterológica. Como se sabe, la sociedad colonial estimaba que cada raza poseía características de temperamento que las diferenciaba. Al igual que las series de vidas de santos, cuando la escena reclama un paisaje, éste lo hará en calidad de «telón de fondo" y no declarará un vínculo estrecho entre el paisaje y los personajes como lo hará la pintura de costumbres decimonónica (basada en la relativa homogeneidad cromática y textural entre los habitantes de un lugar y el paisaje, de acuerdo a la premisa romántica), salvo como indicativo del lugar que efectivamente habitan sus personajes. A su vez, la retórica interior-exterior se incorpora a la pintura de castas, cuyas fuentes compositivas radican en las series de vidas de santos. En cambio, aquellas que sitúan la escena en un paisaje, parecen depender de la nueva posición del horizonte adoptada por la escena de batalla a fines del siglo XVIII. Los personajes se "sostienen» sobre la horizontal normal de suerte que la vertical normal, genera la principal oposición semántica (Fig. 3). El plano de tierra asciende sobre la horizontal normal dando la oportunidad de describir, gracias a la generación de espacios narrativos creados con diversos elementos iconográficos (arquitectura: una choza; elementos de la naturaleza: un claro entre el ramaje de los árboles), las diversas tareas que son propias de la raza para las que los habilita su particular temperamento. $\mathrm{O}$ bien, desciende por debajo de la horizontal normal, para situar la figura del personaje en las inmediaciones de la vertical normal, generando con ello, la apertura de espacios simétricos para la descripción de sus atributos (Fig. 4). Sin embargo, la pose y distribución de masas no responden necesariamente a las del libro, concentradas como están en la caracterización tipológica de los personajes, sino más bien en la escena de género. 


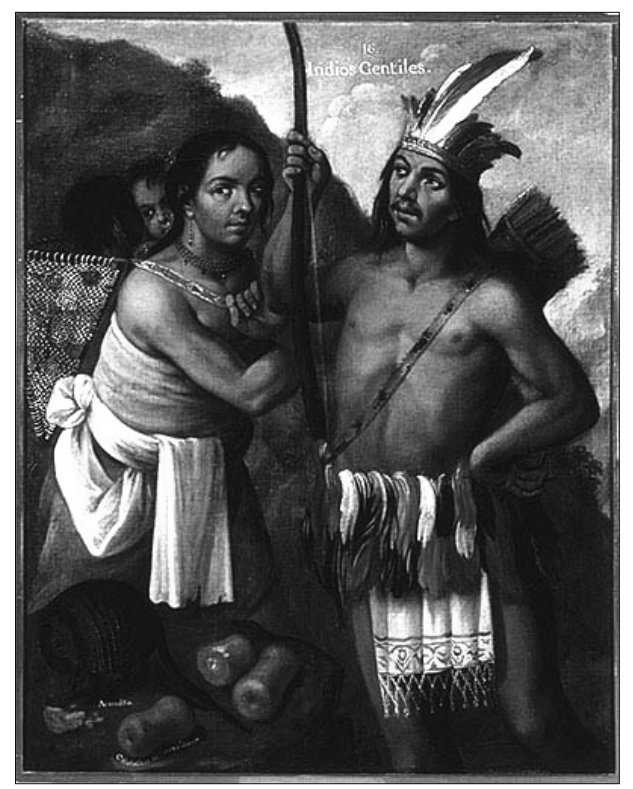

Fig. 3. Miguel Cabrera: Yndios Gentiles, 1763, óleo sobre lienzo, 132 × $103 \mathrm{~cm}$. Cortesía del Museo de América, Madrid.

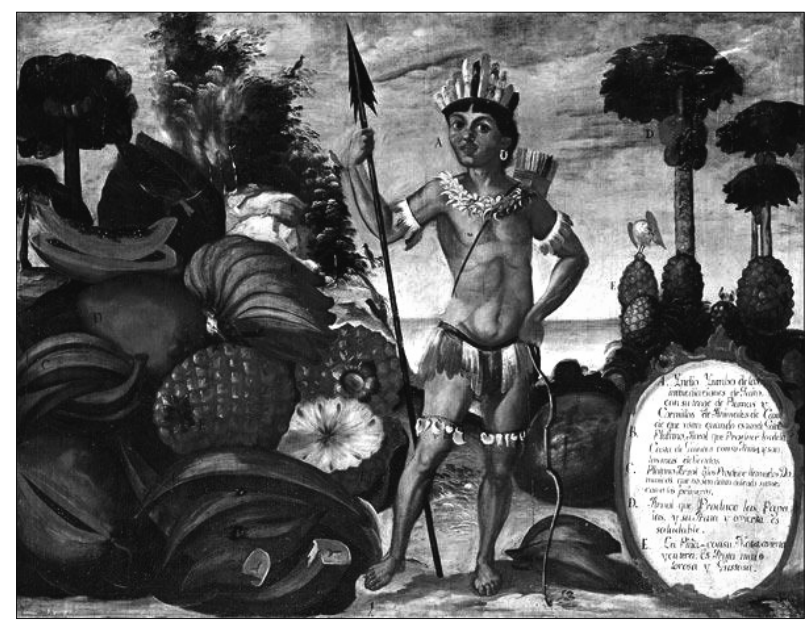

Fig. 4. Vicente Albán: Indio yumbo de las inmediaciones de Quito, 1783, óleo sobre lienzo, 80 x $109 \mathrm{~cm}$. Cortesía del Museo de América, Madrid.

¿Cómo se verificó el proceso de constitución de la escena de género? Esta compleja pregunta ha encontrado generalmente respuesta considerando la notable ampliación de mercado que experimentaron los países protestantes, es decir, la constitución de un mercado burgués que aspira legitimarse y reconocerse en un cierto tipo de pintura. La naturaleza «laboral» de la burguesía encontró caracterización en la representación más 
o menos explícita de las actividades propias de la clase social representada y habría dado cabida a una nueva variación temática y compositiva, el retrato colectivo o de guilda. Por esta razón, por el hecho de que describe o alude a acciones, la escena de género habría de recurrir a la pintura de historia para encontrar algunas de sus soluciones compositivas. A su vez, en los países católicos la escena de género apoyándose también en la pintura de historia, encontró mayormente sus campos temáticos no en las necesidades de auto representación de la burguesía, sino en la función moralizante que, desde un principio, cumplió la pintura de historia. Evidentemente no estamos afirmando que esta clasificación funcional y temática de la escena de género sea rígida e inamovible; solo afirmamos que, grosso modo, es factible organizar primariamente esta producción de esta manera. En cambio, nos resulta más atractivo el examen de los modelos compositivos de la pintura de historia y de la escena de género entre los siglos XVI y XVII, en la medida en que la lógica del encuadre y el ascenso/descenso del ojo en relación a la horizontal normal consolidaron dos modos de representación del cuerpo: cuerpo entero y medio cuerpo. Más aún, la pintura de historia religiosa, por ejemplo la pintura de escenas de martirio, agregó un nuevo recurso iconográfico a la consecución de la superposición narrativa: a través de los cuerpos, muchas veces retorcidos, de santos, mártires y torturadores, el espectador se abre paso hacia un nuevo momento narrativo, que generalmente se desarrolla "al interior» de la pintura. ${ }^{2}$ A su vez, si bien los formatos verticales abundan, no cabe duda de que los formatos apaisados se privilegiaron para consumar la exposición de la historia. A este respecto convendría agregar lo siguiente: la disposición de las superficies pictóricas son también parte de lo que conocemos como "rasgos estilísticos» propios del estilo y, como tales, participan del gusto imperante: el consumidor está esperando un cierto tipo de objeto cuya apariencia visual concibe como propio y característico del género.

Ahora bien, mediante el recurso de la descripción de objetos u atributos de las actividades y del entorno de realización de dichas actividades, la escena de género posibilitó una suerte de «integración» de géneros pictóricos en la medida en que consolidó una cierta retórica interior-exterior que establecía su propia función autorrepresentacional de la burguesía y/o moralizante. Para América Latina, dicha integración se verifica fundamentalmente en la pintura de castas y en las series de vidas de santos. Tanto la una como la otra tienen también sus antecedentes en las variaciones compositivo-narrativas de la pintura gótica. Y, desde la perspectiva global de la producción de los talleres coloniales, la pintura religiosa parece responder nítidamente a un criterio iconográfico y compositivo que remite a un gusto férreamente instituido, generando con ello la diversidad estilística entre obras producidas por un mismo taller. Por ello la pintura de castas nos permite observar lo siguiente: existirían en ella al menos dos modelos compositivos dominantes: aquel que recurre a las series de vidas de santos (que, como hemos visto, coincide en recursos compositivos con la escena de género) y aquel que lo hace con la escena de batalla dieciochesca. Esta organización, a su vez, permitiría afirmar que la escena de castas difiere del modelo que analizaremos, en el sentido de que sus fuentes compositivas son eminentemente pictóricas y en cuanto a que sus funciones moralizantes son de índole expresamente narrativa, en el sentido tradicional de la pintura de historia. De esta manera, la pintura de castas constituye un antecedente parcial de lo que será la escena de costumbres del periodo comprendido entre fines del Siglo XVIII y los primeros cuarenta

Pienso sobre todo en las representaciones de santos mártires de Sebastiano del Piombo o, más tarde, Jusepe Ribera. 
años del siglo XIX. Así, queda todavía preguntarse por las fuentes compositivas de la escena de costumbres y de la representación tipológica en sentido social y cultural.

\section{ALGUNAS INNOVACIONES COMPOSITIVAS DEL BARROCO Y EL TARDOBARROCO QUE CONCURREN EN EL GÉNERO ESCENA DE COSTUMBRES}

A la convención generalizada de reconocer al Rococó un enorme impulso a las artes útiles, se le anexa aquella que sitúa en el Tardobarroco el origen de sus orientaciones temáticas y estéticas. Una de esas orientaciones estéticas, de particular interés para este análisis, es la aparición de un nuevo tipo de imágenes pictóricas, en primer lugar, la ve$d u t a$, es decir, las grandes vistas paisajísticas antecesoras del paisaje romántico; por otra parte, el capricho, o paisaje imaginario, ${ }^{3}$ finalmente, la escena pintoresca, que alcanzará su máxima popularidad a lo largo de la segunda mitad del siglo XVIII, es decir, en el tránsito mismo del Rococó hacia el Neoclasicismo, y que verifica asimismo un tránsito en su orientación estética desde un escenario puramente bucólico y descriptivo hacia la alegoría con fines moralizantes que enlaza con el Neoclasicismo.

Los dos primeros tipos de imágenes (la veduta y el capricho) tienen en común al menos las siguientes características: ubican el horizonte generalmente por debajo de la horizontal normal de la superficie pictórica, reorganizan el encuadre para responder a la idea de la panorámica, prefiriendo entonces una disposición apaisada y, consecuente con esta reorganización, prefieren las perspectivas fugadas, emparentadas con el trampantojo propio de la pintura mural palaciega. La escena pintoresca, que transcurre ya en interiores ya con un paisaje como telón de fondo, en cambio, aunque se nos ofrece en una doble disposición, ya sea vertical, ya sea apaisada, comparte con aquellas la predilección por el descenso del horizonte. En este sentido hay que convocar aquí a la pintura de caballete dieciochesca, pensada para las decoraciones palaciegas y que, en cierto sentido, trasladaban este tipo de composición hacia la escena pintoresca, como bien ejemplifican en España Giovanni Doménico Tiépolo o Francisco de Goya, quienes además, proveían de imágenes a los talleres reales (Fig. 5). Simultáneamente, habría que recordar aquí las escenas pintorescas chinescas que poblaron las artes útiles. Si bien la chinoiserie francesa tuvo un eventual origen en el éxito de la pintura decorativa de Boucher y contó con la apertura del comercio europeo con China, así como con el rediseño de las rutas comerciales, debemos recordar, una vez más, que este tipo de pintura tuvo una contraparte pintoresca, es decir, con temas locales, cuyos orígenes históricos bien pueden rastrearse a los libros de horas, y que, por otra parte, contaron con un notable desarrollo en las artes útiles americanas, en particular en el México de fines del siglo XVII y a todo lo largo del XVIII. Como se sabe, la escena pintoresca, una suerte de derivado de la escena de género, se caracterizó por ofrecer un doble campo discursivo cuyo horizonte común es la alegoría moralizante. Sus regímenes compositivos, también duales, parecen provenir desde dos frentes: por un lado la tradición compositiva de la escena de género, en su formato apaisado y, por otro lado, la caracterización tipológica cuyo principal espacio discursivo se inscribe en la oposición campo-ciudad que en el dieciocho devendrá propiamente civilización-barbarie,

\footnotetext{
Recuérdese que si bien esta nomenclatura es característica del Tardobarroco italiano, este tipo de temas y
} composiciones fueron practicadas en toda Europa. 
discurso enrarecido, como también se sabe, por la naciente concepción romántica de "pueblo». En efecto, mientras la escena pintoresca buscaba retratar al pueblo desde una perspectiva más bien bucólica, eventualmente ligada al capricho, la pintura galante privilegió otro sistema compositivo, en el que la función moralizante se verificaba por la vía del voyeurismo. ${ }^{4}$

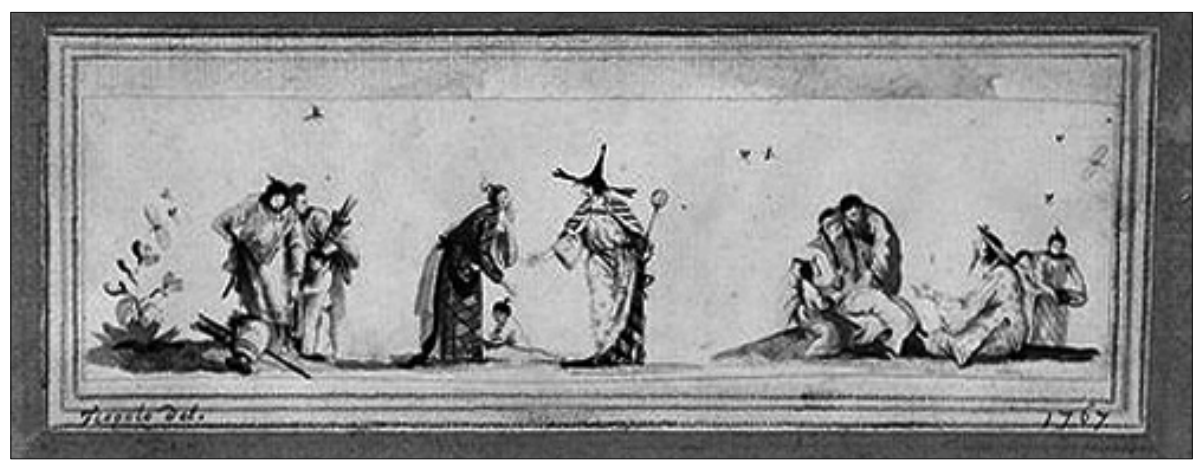

Fig. 5. Giovanni Battista Tiépolo (atr.): Chinoiserie, 1767, grafito, acuarela, tinta negra y blanca sobre papel montado sobre papel, 5,1 x 18,4 cm. Cortesía del Museo Fogg, The Harvard University Museums, Harvard.

A su vez, si para el Barroco las relaciones entre el desarrollo de la cartografía y la pintura de países, antecesora del paisaje, han sido profusamente estudiadas, como también ha sido abordada la literatura que aparece en los inicios del periodo barroco y que se dedica a difundir los hábitos, costumbres y apariencia general de los habitantes de lugares remotos y que evidentemente estaba relacionada con la crónica de viajes, ellas han sido consideradas exclusivamente desde el punto de vista temático y se ha pasado por alto la correspondencia compositiva que dichas imágenes tienen con las caracterizaciones tipológicas realizadas en América Latina a lo largo del siglo XVIII y hasta bien entrada la década del 40 del siglo XIX.

\section{DEL LIBRO A LA TELA Y AL OBJETO}

El conjunto de consideraciones expuestas nos permite considerar este gusto dieciochesco como uno en que se yuxtaponen dos mercados: un mercado artístico, culto, cortesano y un mercado mucho más amplio que posibilita el consumo de ciertas características de las imágenes en su capacidad evocadora, verosímil y descriptiva, en sentido categórico y tipológico, mercado que respalda al campo culto y que se sustenta en el libro. Las estrategias

\footnotetext{
$4 \quad$ La pintura galante ofreció un nuevo espacio de autonomía para el desnudo como género, a pesar de permanecer sometido a las exigencias narrativas de la pintura de historia. Como es evidente, esta caracterización de la pintura galante propone un nuevo problema en relación al desnudo y las estrategias del gusto en función de la disposición de la figura a lo largo de la horizontal normal, en oposición a la composición apaisada en $2 / 3$ o 3/4. En efecto, podría argüirse que el desnudo encontró en la segunda mitad del dieciocho un nuevo modelo compositivo que estableció una suerte de contradicción entre el anclaje de la figura en la horizontal normal y la política del voyeur, quedando esta última circunscrita a los recursos iconográficos y a la relativa clausura del juego de miradas entre el personaje y el espectador.
} 
diagramáticas de las páginas del libro, así como el carácter ilustrativo y, por ende, sintético, de sus imágenes sugieren estrategias compositivas para dichas imágenes que han de ser consecuentes con los modos de recepción del objeto mismo en que circulan. Los casos, ampliamente conocidos, de los Habiti Antichi et Moderni de Cesare Vecellio y de la China Monumentalis de Atanasio Kirchner nos ofrecen un primer espacio de argumentación necesario. La obra de Vecellio, primo del Tiziano, nos presenta lo que podemos llamar el «modelo estándar» (Fig. 6) de las ilustraciones de este tipo: en efecto, sobre el fondo vacío de la página, y encuadrada de acuerdo a la composición áurea, sobre la vertical normal del recuadro de imagen, se ubican las figuras de los habitantes de tierras remotas; su pose recurrente es en tres cuartos, aunque en ocasiones los individuos se nos presentan de medio perfil. La ausencia de toda suerte de información visual sobre el espacio en que se encuentra la figura nos permite concentrarnos en sus atributos. La constante de estas imágenes es la posición del plano de tierra, ubicado casi a ras de los pies, línea de tierra consistente con uno de los ejes horizontales que administran las cajas de texto. Una situación opuesta presenta el libro de viajes de Kirchner (Figs. 7 y 8). Ilustrado por él mismo, el libro contiene dos tipos de imágenes, por un lado aquellas que no escatiman esfuerzos por contextualizar las figuras y acciones descritas en el texto, en las que la línea del horizonte rara vez desciende por debajo de la horizontal normal y, en cambio, con relativa frecuencia asciende sobre ella, destinadas a presentar un entorno cultural o un paisaje poblado de fauna o de individuos; por otro lado aquellas que, como las de Vecellio, sitúan la línea de tierra por debajo de la horizontal normal y que se destinan especialmente para la caracterización tipológica. Es precisamente en esta tradición, en la que el horizonte desaparece también lo hace el paisaje, para dejar en su lugar apenas una indicación del plano de tierra, la que en definitiva se perpetúa en las ilustraciones de las expediciones científicas posteriores. Por otra parte, la tradición de publicaciones destinadas a la descripción de hábitos y costumbres de culturas lejanas es la que todavía se perpetúa en vastos segmentos de la producción anónima de pintura de castas como bien demostrara Ilona Katzew (2004) y es esta misma tradición, la que una vez más aparece en las acuarelas de Pancho Fierro, producidas a mediados del siglo XIX, o en los dibujos del vasco radicado en Cuba, Víctor Patricio Landaluce, realizados en la misma época. Esta tradición había cobrado fuerza con las series de colecciones de estampas que se habían publicado en Europa desde principios del siglo XVIII y que describían pregones o vestimentas y que son, a su vez, consideradas como antecedentes de las series literarias y dibujísticas que se publicaron en México, Cuba, España, y que llevaron por título, Los Mexicanos pintados por sí mismos, Los cubanos pintados por sí mismos, etc., tal y como ha demostrado María Esther Pérez Salas (1998). ${ }^{5}$ Estas publicaciones, por otra parte, fueron dando cuerpo a la literatura costumbrista del siglo XIX, de suerte que, en cuanto cuadro de costumbres (nombre con el cual se las englobaba) acompañan a la producción de escenas de costumbres y a la pintura de costumbres de la segunda mitad del siglo XIX.

\footnotetext{
Además de "Genealogía de los Mexicanos pintados por sí mismos» en Historia Mexicana, la autora publica en el año 2005, Costumbrismo y litografía costumbrista en México durante la primera mitad del siglo XIX.
} 


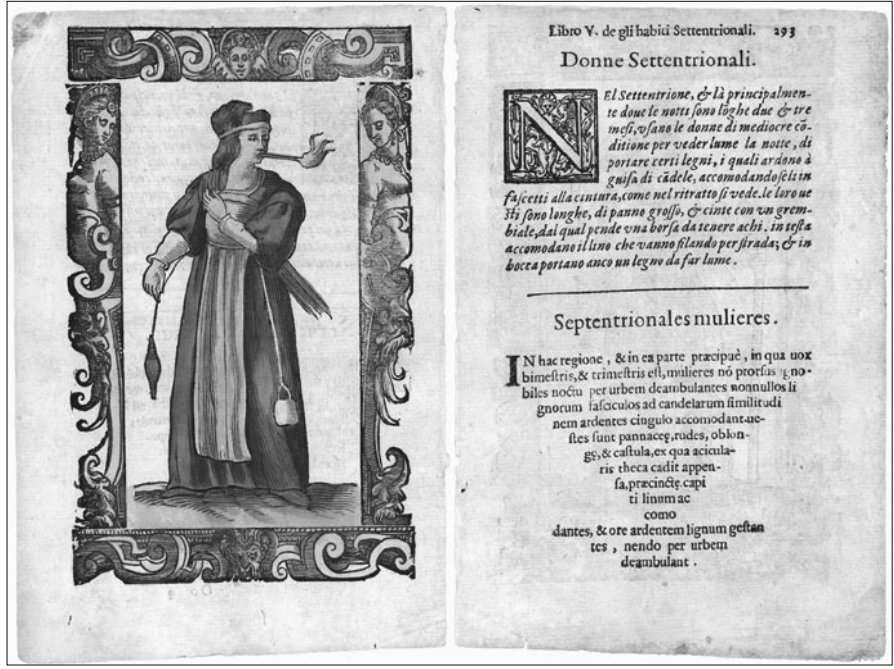

Fig. 6. Cesare Vecellio: Mujer del Septentrión. Habiti Antichi et Modern, 1559. Cortesía de la Biblioteca Nacional de Noruega, Oslo.

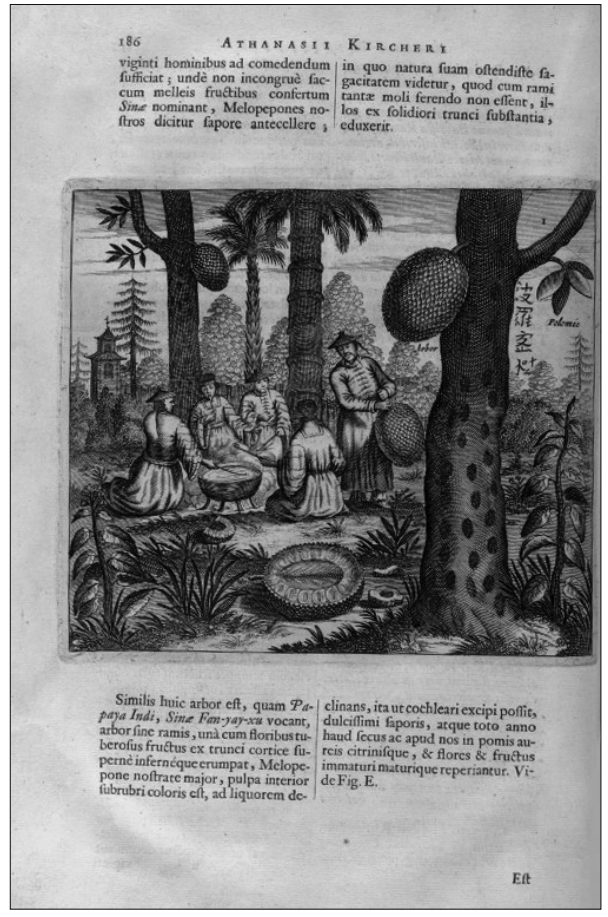

Fig. 7. Atanasio Kircher: Descripción de árboles frutales. China Monumentis, 1667. Cortesía del Instituto Max Planck, Berlín. 


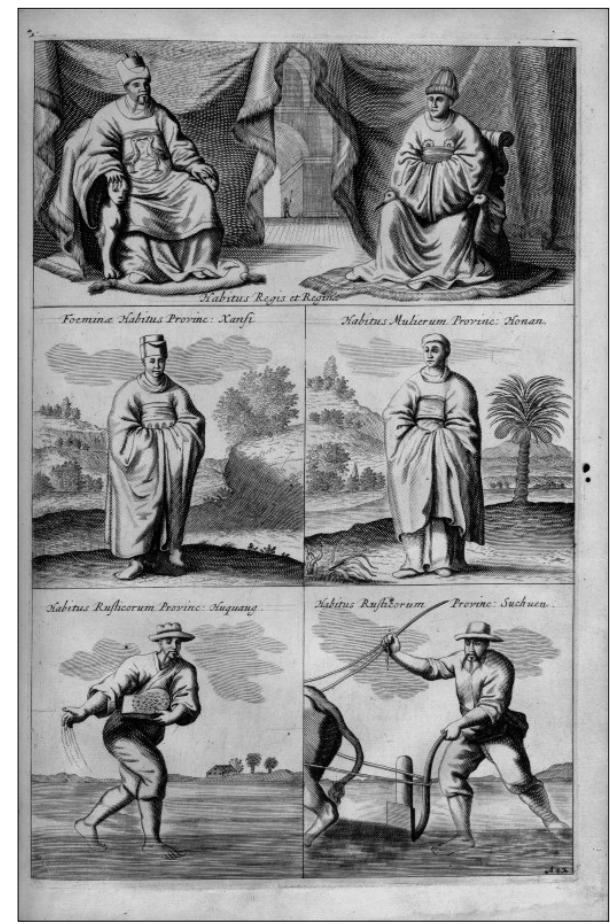

Fig. 8. Atanasio Kircher: Campesinos. China Monumentis, 1667, Cortesía del Instituto Max Planck, Berlín.

De la misma manera, el crecimiento de las artes útiles y la demanda epocal por decorar dichos objetos con escenas de costumbres no sólo había acompañado a esas publicaciones, sino que también permitieron la circulación de estas imágenes colaborando en el proceso de su conversión en temas de encuadre, como denomina Bialostocki (1974: 11124) al proceso según el cual un repertorio iconográfico organizado, en torno a temas de carácter arquetípico, se constituye en referente obligatorio del campo semántico que les subyace, a pesar de los giros epocales. En nuestro caso, la proposición de Bialostocki está siendo conducida al aspecto semántico-compositivo del género pintura de costumbres.

En sentido inverso, desde temprano los artistas coloniales proveyeron a la Corona de imágenes que se inscribían en el género pintura de historia, pero que, por otro lado, respondían a las dinámicas de ilustración de la reciente literatura científica y naturalista, incluida la crónica de viajes. Imágenes que, como lo hará más tarde la pintura de castas, identificaban con una letra o un número los distintos momentos de la escena, que a continuación eran anclados verbalmente en el tradicional recuadro de texto.

\section{DE LA PINTURA A LA PINTURA}

Si la ilustración de libros, las colecciones de estampas o los cartapacios de viajes ofrecieron a las imágenes que discutimos su propio régimen compositivo, fundado de modo 
triple en la función ilustrativa de las imágenes, en las convenciones de la diagramación y en los medios de recepción del objeto en cuyo interior circulaban, el lugar común de la tradición del continuo es la de situar en otras obras de arte los antecedentes de aquellas que se están examinando. En este sentido, las raíces barrocas pueden encontrarse en las composiciones en abismo, estudiadas por Stoichita (2000) y que, procedentes del espejo, se presentan bajo la forma de paisaje con escena de costumbres, paisaje que se derrama a nuestros pies o nos introduce dentro de la imagen en un verdadero descenso al abismo. En el Rococó, como en el Tardobarroco, una solución recurrente para este tipo de imagen consistió en el uso y abuso del contrapicado y caída del horizonte de la escena pintoresca, en lo que parece ser un descenso de las figuras desde el cielo de las imágenes hasta nuestros ojos. Sin embargo, parece más plausible la dependencia de la inicial pintura de costumbres decimonónica, con las transformaciones compositivas de la pintura de historia a finales del XVIII, transformaciones que supusieron la adopción de la lógica de la panorámica para la escena de batalla, con el consecuente descenso o ascenso del horizonte, en la misma medida en que el paisaje conservaba su función de telón de fondo, tal y como lo había sido, por ejemplo, para los artistas latinoamericanos del siglo XVIII. En efecto, la pintura de castas, verifica la misma convención según la cual, la escena de género y la escena de costumbres constituyen un subgénero de la pintura de historia y las escenas secundarias o la naturaleza muerta que comportan, responden a la misma dinámica especular de la composición en abismo antes citada. Para el caso específico del paisaje como telón de fondo, recuérdese que la nueva posición que ocupa el horizonte en la escena de batalla, limitando con la panorámica, genera la sensación de una escena que transcurre paralela al horizonte, a través de su estructuración a lo largo de la horizontal normal. Así, la percepción de la profundidad queda entregada a los efectos cromáticos produciendo con ello una relativa sensación de irrealidad, puesto que el mecanismo estructurante concentra en el dibujo y el detalle, el grueso del interés de la composición. Un argumento que podemos esgrimir aquí es que, una vez más, la escena de batalla, en cuanto subgénero de la pintura de historia, cumplía no sólo una función memorativa sino ante todo moralizante, al ofrecer comportamientos emulables. Como sea, una vez más se trata de la función cognoscitiva, pedagógica y reflexiva que históricamente Occidente atribuyó al dibujo.

En este sentido, hay que destacar no sólo la función difusora del ideario exotista de los artistas viajeros, sino ante todo el conjunto de convenciones pictóricas que popularizó entre nosotros la instalación de la Academia y las prácticas pedagógicas que la sostuvieron (Rafael Gutiérrez y Ramón Gutiérrez, 1999). En efecto, es el proceso académico el que instaló definitivamente entre nosotros la jerarquía temática, aun cuando los artistas coloniales estuvieran en conocimiento de ella, así como de otro conjunto de convenciones que atañen a la teoría del arte, como lo demuestran los recientes descubrimientos en los archivos Mexicanos que, ya desde el siglo XVIII, como lo testimonian Miguel Cabrera (1785) en su calidad de pintor, o en el presente la investigadora Paula Mues Orts (2006), o los documentos sobre las prácticas pedagógicas académicas que han rescatado jóvenes investigadores brasileños, por ejemplo Elaine Dias (2004) o Jorge Coli (2005). Estos últimos documentos han hecho visible el grado de actualización que las academias significaron, no sólo en lo que corresponde a cuestiones estilísticas o temáticas, sino ante todo en lo relativo a la construcción de un vocabulario mínimo que posibilitara la reflexión sobre el arte, tal y como se confirmará más tarde con las reflexiones que en Chile, México o el Brasil redactaron nuestros artistas en torno a la urgencia de desarrollar el género pintura 
de historia, a partir de mediados del siglo XIX, en el contexto de los procesos de expansión territorial, por una parte, y de modernización, por la otra, argumentación que tuvo en la práctica «adecuada» y «correcta» del dibujo, uno de sus ejes principales.

En el ínterin, es decir, entre fines del XVIII y la década del 40 del siglo XIX, los regímenes compositivos de la escena de costumbres, como hemos visto, parecen responder a estas dos tradiciones: la tradición ilustrativa de los relatos de costumbres y las tradiciones pictóricas de la veduta tardobarroca y de la escena pintoresca del Rococó. Más aún, estas convenciones compositivas son aplicables con relativa certeza a las ilustraciones científicas de los artistas viajeros que acompañaron a los naturalistas del fin del XVIII y principios del XIX. En este sentido, disiento de la interpretación de Penhos (2005) por cuanto subordina excesivamente las imágenes al texto de Malaspina. En otras palabras, las imágenes no tendrían otro campo de sentido que las del texto. En efecto, no sólo la reproducción de imágenes sino el vasto universo de objetos utilitarios decorados con imágenes con temas similares a las que se les estaban exigiendo, evidentemente constituyeron un banco de referencias iconográficas que los artistas no podían obviar de manera consciente. En el bando opuesto, los artistas latinoamericanos que inician la pintura costumbrista no sólo cuentan con los recientes modelos europeos provistos por los artistas viajeros, sino ante todo con dos campos generales de referencia: las ilustraciones en libros y las más recientes convenciones compositivas, no estilísticas en sentido general, de las primeras academias.

\section{EPÍLOGO}

Si bien las investigaciones que pretendan ahondar en este enfoque requieren para su realización de un decidido estrechamiento de lazos entre investigadores e instituciones continentales y considerar un conjunto amplio y heterogéneo de fuentes, por otro lado esa misma amplitud en la índole y manipulación de las fuentes, en virtud de las cuales la larga tradición de historiadores de la cultura y del gusto reflotan del limbo en que han sido arrojados, permitirá superar la estrecha instrumentalización y polarización excesivas con que han sido entendidas tanto las relaciones de poder como la autoconciencia racial, que han solidificado un mapa de transferencias que legitima periodizaciones específicas para cada tipo de objeto con la consecuente estrechez con que concebimos el concepto de imagen. Por ello, enfoques de esta naturaleza permiten redibujar el mapa de las transferencias y procesos de constitución de los géneros pictóricos en América Latina, en la misma medida en que conciben los campos semánticos de las imágenes como estructuradas sobre un campo relacional entre objetos, cuyo marco condicional estriba tanto en las demandas epocales, como en los mecanismos de consumo de las imágenes, en relación a los procesos de ampliación y restricción de campos semánticos desde y en los regímenes compositivos. Por ello, este modelo permitiría examinar la pintura de costumbres desde dinámicas del gusto mucho más amplias que las atribuidas de modo inmanente al concepto de estilo, al mismo tiempo que retoma el diálogo entre las imágenes y en cuanto imágenes, distanciándose tanto de la reducción iconográfica, como de la subordinación al texto. Así, no se trata ni de negar la especificidad de las imágenes producidas en América, ni de obviar las interrelaciones iconográficas de la pintura consigo misma, a ambos lados de globo. Más bien, se trata de asumir la inscripción del arte latinoamericano en las 
lógicas constructivas de imágenes en Occidente, examinándolas desde una concepción no sólo iconográfica sino también estética y entendiendo a ésta como integrante de la experiencia en general. Por otra parte, modelos como éste, someramente expuestos aquí, dada su operatividad sobre un amplio espectro de objetos concebibles desde la noción de imagen, permiten examinar espacios de transitividad de campos semánticos entre objetos, artísticos y utilitarios, con el consecuente rendimiento sobre cuestiones tanto iconográficas como iconológicas y, por ende, volver a mirar algunos de los mecanismos y procedimientos a través de los cuales América Latina ha dado cuerpo a su producción visual.

\section{REFERENCIAS}

Bialostocki, Jan. (1973). Estilo e iconografía. Contribución a una ciencia de las artes. pp. 111-124. Barcelona: Barral.

Calvo Serraller, Francisco. (2005). Los géneros de la pintura. Madrid: Taurus.

Carrera, Magaly Marie. (2003). Imagining Identity in New Spain: Race, Lineage and the Colonial Body in Portraiture and Casta Painting. University of Texas Press.

Coli, Jorge. (2005). Como estudar a arte brasileira do século XIX? Sao Paulo: Senac.

Dias Elaine. (2004). La Academia de Artes brasileña en la primera mitad del siglo XIX: rivalidades artísticas e institucionales entre franceses, portugueses y brasileños. En Fernando Guzmán, Gloria Cortés y Juan Manuel Martínez (comps.). Arte y crisis en Iberoamérica. Segundas Jornadas de Historia del Arte. pp. 95-101. Santiago: Universidad Adolfo Ibáñez-Ril Editores.

Gállego, Julián. (1972). El cuadro dentro del cuadro. Madrid: Cátedra.

Graham María. (1837). Journal of a Voayage to Brazil and Residence There During Part of the Years 1821, 1822, 1823. Londres: Longman, Hurs, Rees, Orme, Brown, and Green, and J. Murray.

Gutiérrez Viñuales, Rodrigo y Ramón Gutiérrez (orgs.). (1997). Pintura, escultura y fotografia en Iberoamérica. Madrid: Cátedra.

Katzew, Ilona. (2004). La pintura de castas. Madrid: Turner Publications.

Kircher, Atanasio SJ. (1667). China monumentis, qua sacris quà profanis, nec non variis natrae \& artis spectaculis, aliarumque rerum memorabilium argumentis illustrata. Amsterdam: Johannes Meurs.

Mues Ortis, Paula. (2006). El arte maestra. Traducción novohispana de un tratado pictórico italiano. Estudio introductorio y notas, Paula Mues Ors. Estudios en torno al Arte, $\mathrm{N}^{\circ}$ 1, México: Museo de la Basílica de Guadalupe.

Penhos, Marta. (2005). Ver, conocer dominar; Imágenes de Sudamérica a fines del siglo XVIII. Buenos Aires: Siglo XXI Editores.

Pérez-Salas Cantú, María Esther. (1998). Genealogía de los Mexicanos pintados por sí mismos. Historia Mexicana, XLVIII: 2 (190). pp. 167-207. Octubre-diciembre. México: Colegio de México.

-. (2005). Costumbrismo y litografía costumbrista en México durante la primera mitad del siglo XIX. México: Instituto de Investigaciones Estéticas.

Pevsner, Nicolás. (1973). Las academias del arte, pasado y presente. Madrid: Cátedra. 
Rodríguez de Campomanes, Pedro. (1774). Discurso sobre el fomento de la Industria Popular. Madrid: Imprenta de D. Antonio de Sancha.

- (1775). Discurso sobre la Educación Popular de los Artesanos y su fomento. Madrid: Imprenta de D. Antonio de Sancha.

Stoichita, Victor. (2000). La invención del cuadro. Madrid: Ediciones del Serbal.

-. (1995). El ojo místico. Pintura y visión religiosa en el Siglo de Oro español. Madrid: Alianza.

Taunay, Félix-Émile. (1837). Epitome de Anatomia Relativa as Bellas Artes seguido de hum compendio de physiologia das paixões, e de algumas considerações geraes sobre as proporções, com as divisões do corpo humano; offerecido aos alumnos da Imperial Academia das Bellas Artes do Rio de Janeiro. Río de Janeiro: Typographia Imperial e Constitucional de J. Villenéuve e comp.

VecellioCesare. (1598). Habiti Antichi e Moderni di Tutto il Mondo, Venecia, Di Cesare Vecellio. Di nuono accreseiuti di molte figure... Per Sulstativm Gratilianum Senapolensis Lative declarati. Venecia: Appresso i Sessa.

Recepción: junio de 2008 Aceptación: diciembre de 2008 